\title{
BIOPSYCHOSOCIAL DETERMINANTS OF MACRO AND MICROVASCULAR COMPLICATIONS IN TYPE 2 DIABETES MELLITUS PATIENTS AT DR. MOEWARDI, SURAKARTA
}

\author{
Handoko'), Setyo Sri Rahardjo²), Bhisma Murti1) \\ ${ }^{1)}$ Masters Program in Public Health, Universitas Sebelas Maret \\ 2)Faculty of Medicine, Universitas Sebelas Maret
}

\begin{abstract}
Background: Type 2 Diabetes Mellitus (Type 2 DM) is one of the major causes of morbidity and mortality worldwide. Morbidity and mortality due to diabetes are associated with the development of various microvascular complications (retinopathy, nephropathy, and neuropathy) and macrovascular complications (coronary heart disease, stroke, and peripheral vascular disease). This study aimed to examine the determinants of biopsychosocial macro and microvascular complications in patients with type $2 \mathrm{DM}$ at Dr. Moewardi Surakarta.

Subjects and Method: This was an analytic observational with a case-control design. The study was conducted at Dr. Moewardi, Surakarta, Central Java, from January to March 2018. A sample of 75 Type 2 DM cases with complication and 75 Type 2 DM cases without complication was selected for this study by fixed disease sampling. The dependent variables were macro and microvascular complications. The independent variables were body mass index (BMI), blood pressure, quality of life, depression, duration of disease, physical activity, diet, medication adherence, health financing, and routine blood sample. Clinical data were taken from medical record. The data of other variables were collected by a set of pre-tested questionnaire. Logistic regression was employed for data analysis.

Results: The risk of macro and microvascular complications in type $2 \mathrm{DM}$ patients increased with high $\mathrm{BMI}(\mathrm{OR}=22.00 ; 95 \% \mathrm{CI}=7.50$ to $64.52, \mathrm{p}<0.001)$, poor quality of life $(\mathrm{OR}=7.06$; $\mathrm{CI} 95 \%=3.51$ to $14.16, \mathrm{p}<0.001)$, depression $(\mathrm{OR}=$ $3.30 ; 95 \% \mathrm{CI}=1.39$ to $7.79, \mathrm{p}=0.007)$, longer duration of disease $(\mathrm{OR}=9.71 ; 95 \%$ $\mathrm{CI}=2.79$ to $33.71, \mathrm{p}<0.001)$, lack of physical activity $(\mathrm{OR}=8.16 ; 95 \% \mathrm{CI}=1.23$ to 53.93, $\mathrm{p}=0.029)$, poor diet $(\mathrm{OR}=3.58 ; 95 \% \mathrm{CI}=1.39$ to $9.18, \mathrm{p}=0.008)$, poor medication adherence $(\mathrm{OR}=4.54 ; 95 \% \mathrm{CI}=1.71$ to $12.05, \mathrm{p}=0.002)$, and irregular blood sample control $(\mathrm{OR}=5.80 ; 95 \% \mathrm{CI}=1.97$ to $14.65, \mathrm{p}=0.001)$.

Conclusion: The risk of macro and microvascular complications in patients with type $2 \mathrm{DM}$ is determined by BMI, quality of life, depression, duration of disease, physical activity, diet, medication adherence, and blood sample control.
\end{abstract}

Keywords: biopsychosocial, macrovascular, microvascular, complications, type $2 \mathrm{DM}$

\section{Correspondence:}

Handoko. Masters Program in Public Health, Universitas Sebelas Maret, Jl. Ir. Sutami 36 A, Surakarta, Indonesia. Email: handhira83@yahoo.co.id.

Mobile: +6285225591917.

Mid-International Conference on Public Health, Best Western Premier Hotel, Solo, Indonesia, 18-19 April 2018 | 243 https://doi.org/10.26911/mid.icph.2018.05.05 